\title{
Technology Impacts on Curriculum of Library and Information Science (LIS) - a United States (US) Perspective
}

\author{
Sharon Hu, Ph.D., \\ Department of Library, Information and Media Studies (LIMS) \\ Chicago State University (CSU), USA \\ chu@csu.edu
}

Paper delivered at a workshop on Global Collaboration of Information Schools, IFLA 2013

Nanyang Technological University, Singapore, August 15, 2013

\begin{abstract}
:
Information technology (IT) has tremendously influenced and changed library and information services at libraries and information agencies. The education of library and information science (LIS) professionals is also strongly impacted by IT, because of the current need for changed competences of professional librarians and information scientists, and the consequent changes of educational pedagogies and instructional techniques. The changes driven by IT have presented a challenge to LIS education. The impacts of IT on LIS education involve the establishment of new curricula for LIS, new LIS course design, new ways to organize the LIS education (e.g. iSchools vs. L-Schools), the different knowledge backgrounds and competencies of LIS faculty, extensive recruitments of LIS students, and the expanded job markets and career opportunities for LIS graduates. In addition, the impacts of IT on LIS education will generate challenges such as the changing educational/instructional environment, competition between LIS education and education from other related subject fields, IT based teaching/instructing techniques, comprehensive assessments of LIS courses compared with other courses, and increasing possibilities for collaborations among LIS educational institutions.
\end{abstract}

This paper will present a quantitative analysis and comparative descriptions of several selected American LIS educational institutions for the above issues and conclude with some emerging trends on the curriculum and educational techniques for LIS education.

\section{Introduction}

Since the end of the 1970s, various information technologies have been applied to library and information services. Starting with the MARC format on cataloging materials to replace card cataloging, Integrated Library Management Systems (ILMS) based on computers and networks were developed as the essential technical systems to automate the operations in libraries and information agencies. ILMS technology includes online public access (OPAC) and other online bibliographic databases for reference services, circulation and inter library loan (ILL) modules for access services, acquisitions and serials control modules, plus cataloging module for technical services functions. Since the 1980s, the internet has enhanced and improved library operations through wide area networks. In the 1990s, web, wireless and multimedia technologies rapidly formatted electronic information resources and changed searching interfaces between information seekers and computer systems (human-machine), which greatly extended and improved information dissemination and information services. The $21^{\text {st }}$ century, as the digital age, is when information technology keeps developing quickly along with the development of various other technologies. In the case of digital technology, we are currently seeing large increases in 
digital resources often called the "Big Data" age, mobile devices and applications with wireless networking, high-speed computers and networks, remotely accessible and large capacity electronic storage (the computing cloud), which tightly merge together information technology with information resources, information management and information services, and deeply impacts and develops information science and information services.

Along with the information technology applied in libraries and information services, the competencies of librarians and information staff must be updated to meet the needs and operations in libraries and information agencies. The skills and knowledge to use information technology are often mentioned in the job requirements for library staff and information specialists. In addition to competencies recommended and discussed by multiple related professional associations, based in the United States, such as the American Library Association (ALA), the Association of College and Research Libraries (ACRL), the Association for Information Science \& Technology (ASIS\&T) and the Association for Library and Information Science Education (ALISE), there are many publications and studies exploring and reporting in detail about these issues, such as early as in 1990s by Yuan Zhou (1996) in his research "Analysis of Trends in Demand for Computer-Related Skills for Academic Librarians from 1974-1994,"; the OCLC report in 2010 "Research Libraries, Risk and Systematic Change" (Michalko, Malpas \& Arcolio, 2010), research articles by Mathews and Pardue in 2009 "The Presence of IT Skill Sets in Librarian Position Announcements", and as Pussadee Nonthacumjane (2011) listed in the article "Key skills and competencies of a new generation of LIS professionals". The competencies for IT related skills and knowledge were generally grouped in libraries' hiring advertisements as "Computer Programming, Networking, Web Development, Project (systems) Management, Systems Development and Systems Applications" (Mathews \& Purdue, 2009, p. 255). In addition to the changes and updates for the competencies of current library positions, new positions related to information technology skills and knowledge are created. Such popular titles of positions are shown in Riley-Huff \& Rholes, 2011, Table 6. p. 134: digital librarian, systems/automation librarian, emerging \& instructional technology librarian, web services librarian, electronic resources librarian, database manager, network librarian, distance education librarian..

The knowledge and skills in information technology needed by LIS professionals are also critically impacting the educational programs in library and information science. As mentioned in multiple research publications and reports, the number and type of information technology related courses are increasing in the curricula of LIS educational programs. Riley-Huff and Rholes performed an analysis of the technology courses offered by 57 ALA-Accredited LIS programs in the United States. They found that "libraries are increasingly searching for and employing librarians with significant technology skill sets.” (Riley-Huff \& Rholes, 2011, p. 134) The research concluded "...there has been a significant increase in the number of technology related courses, but the numbers of technology courses vary considerably from program to program and the content of individual courses appears to vary considerably as well" (p. 139), and concluded from their survey that "...the (library) administrators perceive the problem of a lack of IT skills/qualifications as more serious than do candidates...” (p. 139). They alsoexplored IT courses provided by LIS schools and categorized the major types of IT courses such as "Database design, development and maintenance, Web Architecture (Web design, development, usability), Broad technology (basics of Library technologies and overviews), Digital Libraries, Systems Analysis and Server Management, Metadata Markup, Digital Imaging, Automation and 
Integrated Library Systems, Networks, Human Computer Interaction, Instructional Technology, Computer Programming, Web 2.0, User IT management and Geographic Information Systems". (p. 132) In 2004, Karen Markey analyzed and reported the "...Educational trends in Library and Information Science Curricula", and found new themes in the curriculum such as "community information system, competitive intelligence, computer-supported collaborative work, electronic commerce, human-computer interaction, information architecture, information design, knowledge management, medical informatics and natural language processing." (p. 333).

"The iSchools organization was founded in 2005", which "focused on specific tracks such as information technology, library science, informatics, and information science." (iSchools Caucus). Now it is composed of 46 LIS educational institutions. It shows that the LIS educational programs have been increasing the number of information technology related courses in the curriculum. To improve and enhance LIS educational programs in response to the needs from library and information services, there are some issues that need to be further explored and discussed, such as:

1. What courses of information technology (IT) should the LIS educational institution (or iSchools) have as the "core" IT courses for a MLIS program?

2. What relationship between the traditional librarianship courses and IT courses should be established in a LIS or iSchool to meet the practical needs from libraries and Information agencies? Or, what types of competencies, or IT skills and knowledge should be required for an LIS graduate?

This paper aims to study these questions.

\section{Methodology}

This research was designed to select the top 14 American LIS educational institutions ranked in 2013 by US News and World Report as the "2014 Best Library \& Information Studies Schools". These 14 LIS Schools are all ALA accredited LIS Schools. There are 57 ALA accredited LIS Schools, those with the rank scores over 3.5 (full mark as 5) were chosen for this study. In addition, some relevant information about those selected LIS Schools were included, such as Membership of iSchools (iSchools Directory), Membership of Web-Based Information Science Education (WISE)_(Membership of WISE), Rank Positions of Information Systems by US News \& World Report, Rank Position of Digital Librarianship by US News \& World Report, and LIS schools that offer IT Degree Programs.(See Table 1. Selective Top 14 LIS Schools). These supplements of information could identify and help to check the technological background of the selective LIS schools. 
Table 1. Selective top 14 LIS schools

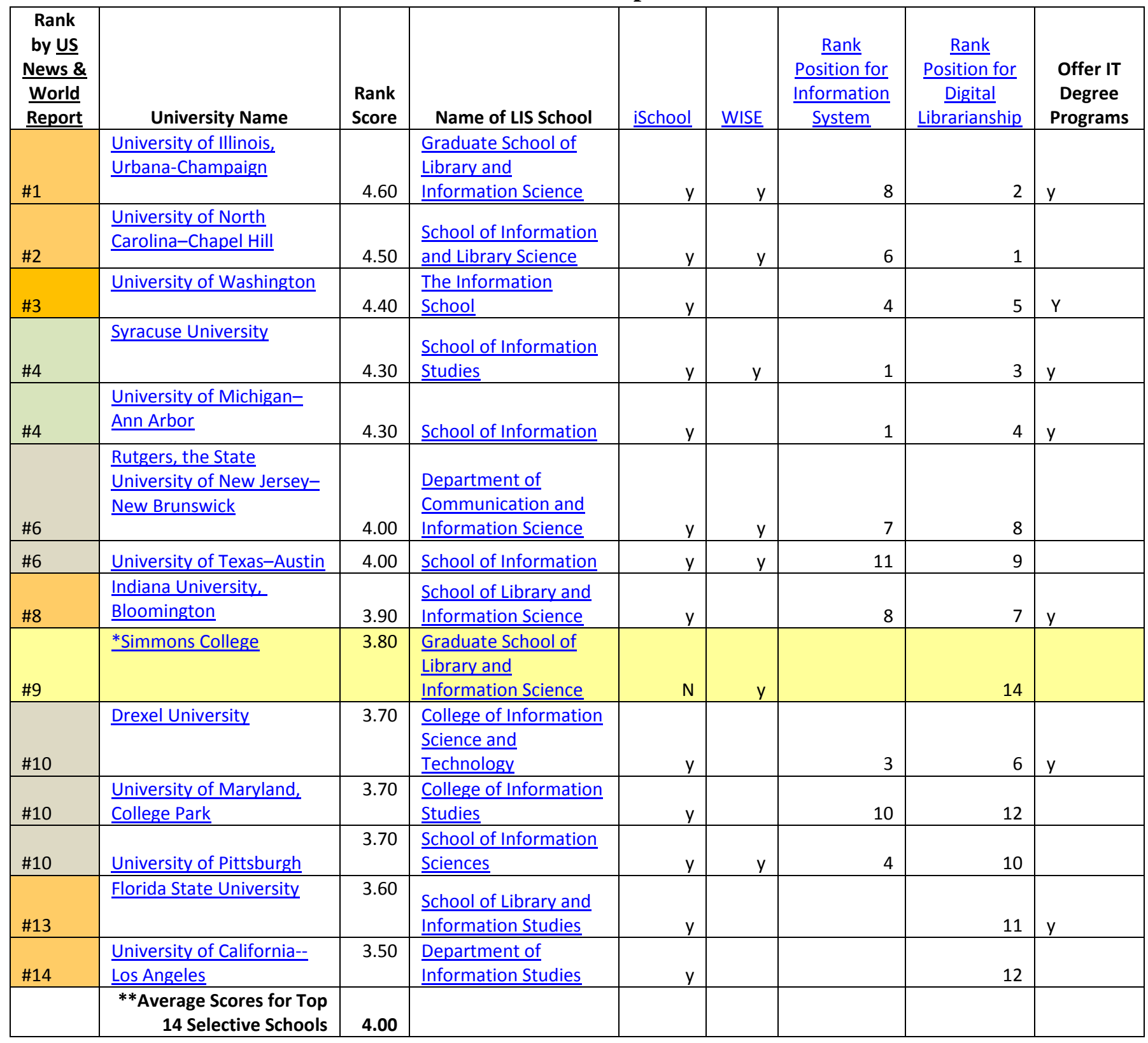

NOTE: 1. Selected Graduate Schools of LIS (Rank score =>3.5) from US News \& World Report 2013 Best Schools Ranking List.

2. Only GSLIS of Simmons College is not iSchool.

The courses reviewed were mostly those courses of graduate programs (Master Degrees and above) from these selected LIS schools. The courses were copied from Courses Catalogs on the website of LIS Schools. If no catalogues of all courses were found on the web site of LIS school, the selected courses were copied from the courses list of academic year 2013-2014 (or 20122013), such as the University of Washington. The courses' titles and descriptions were used to make judgments in this research to review whether the courses were IT related; some courses might also include prerequisites, determined by reviewing the syllabus, if available and necessary. All the IT related courses were further grouped into four popular IT categories: 
Web/Social Networks, Digital Resources/Metadata, Computers /Networks /Programming, Database Design and System Management as shown in Table 2 below.

Table 2. Selective LIS schools with their IT courses in programs

\begin{tabular}{|c|c|c|c|c|c|c|c|c|}
\hline $\begin{array}{r}\text { Rank } \\
\text { by US } \\
\text { News } \\
\text { \& } \\
\text { World } \\
\text { Report } \\
\end{array}$ & University Name & Name of LIS School & $\begin{array}{l}\text { Total } \\
\text { Number } \\
\text { of } \\
\text { Courses } \\
\text { listed in } \\
\text { Catalog }\end{array}$ & $\begin{array}{l}\text { Number of } \\
\text { IT Courses } \\
\text { (\% of Total } \\
\text { Number of } \\
\text { Courses) }\end{array}$ & $\begin{array}{l}\text { Web / } \\
\text { Social } \\
\text { Networks } \\
\text { (\% of } \\
\text { Number } \\
\text { of IT } \\
\text { Courses) }\end{array}$ & $\begin{array}{l}\text { Digital } \\
\text { Resource/ } \\
\text { Metadata } \\
\text { (\% of } \\
\text { Number of } \\
\text { IT Courses) }\end{array}$ & $\begin{array}{r}\text { Computers } \\
\text { /Networks } \\
\text { /Programmin } \\
\mathrm{g}(\% \text { of } \\
\text { Number of IT } \\
\text { Courses) } \\
\end{array}$ & $\begin{array}{l}\text { Database } \\
\text { Design / } \\
\text { System } \\
\text { Management } \\
\text { (\% of Number } \\
\text { of IT Courses) }\end{array}$ \\
\hline$\# 1$ & $\begin{array}{l}\text { University of Illinois, } \\
\text { Urbana-Champaign }\end{array}$ & $\begin{array}{l}\text { Graduate School of } \\
\text { Library and } \\
\text { Information Science }\end{array}$ & 254 & $71(28 \%)$ & $22(31 \%)$ & $22(31 \%)$ & $8(11 \%)$ & $19(27 \%)$ \\
\hline$\# 2$ & $\begin{array}{l}\text { University of North } \\
\text { Carolina-Chapel Hill }\end{array}$ & $\begin{array}{l}\text { School of Information } \\
\text { and Library Science }\end{array}$ & 137 & $43(32 \%)$ & $13(30 \%)$ & $12(28 \%)$ & $4(10 \%)$ & $14(32 \%)$ \\
\hline$\# 3$ & $\begin{array}{l}{ }^{*} \text { University of } \\
\text { Washington }\end{array}$ & $\begin{array}{l}\text { The Information } \\
\text { School }\end{array}$ & 125 & $39(32 \%)$ & $7(18 \%)$ & $8(20 \%)$ & $4(11 \%)$ & $20(51 \%)$ \\
\hline$\# 4$ & Syracuse University & $\begin{array}{l}\text { School of Information } \\
\text { Studies }\end{array}$ & 106 & 51 (49\%) & $12(23 \%)$ & $11(22 \%)$ & $9(18 \%)$ & $19(37 \%)$ \\
\hline$\# 4$ & $\begin{array}{l}\text { University of } \\
\text { Michigan-Ann Arbor }\end{array}$ & School of Information & 146 & 89 (62\%) & $21(24 \%)$ & $19(22 \%)$ & $24(26 \%)$ & $25(28 \%)$ \\
\hline$\# 6$ & $\begin{array}{l}\frac{\text { Rutgers, the State }}{\text { University of New }} \\
\text { Jersey-New } \\
\text { Brunswick }\end{array}$ & $\begin{array}{l}\text { Department of } \\
\text { Communication and } \\
\text { Information Science }\end{array}$ & 63 & $11(18 \%)$ & $2(19 \%)$ & $5(43 \%)$ & $2(19 \%)$ & $2(19 \%)$ \\
\hline$\# 6$ & $\begin{array}{l}\text { University of Texas- } \\
\text { Austin }\end{array}$ & School of Information & 146 & $28(20 \%)$ & $6(37 \%)$ & $12(21 \%)$ & $3(9 \%)$ & $7(33 \%)$ \\
\hline$\# 8$ & $\begin{array}{l}\text { Indiana University, } \\
\text { Bloomington }\end{array}$ & $\frac{\text { School of Library and }}{\text { Information Science }}$ & 102 & $33(33 \%)$ & $12(36 \%)$ & $7(21 \%)$ & $3(10 \%)$ & $11(33 \%)$ \\
\hline$\# 9$ & *Simmons College & $\begin{array}{l}\text { Graduate School of } \\
\text { Library and } \\
\text { Information Science }\end{array}$ & 137 & $(24 \%)$ & $12(36 \%)$ & $11(34 \%)$ & $1(3 \%)$ & $9(27 \%)$ \\
\hline$\# 10$ & Drexel University & $\begin{array}{l}\text { College of Information } \\
\text { Science and } \\
\text { Technology }\end{array}$ & 113 & $47(42 \%)$ & $14(30 \%)$ & $7(15 \%)$ & $10(20 \%)$ & $16(35 \%)$ \\
\hline$\# 10$ & $\begin{array}{l}\text { University of } \\
\text { Maryland, College } \\
\text { Park }\end{array}$ & $\begin{array}{l}\text { College of Information } \\
\text { Studies }\end{array}$ & 45 & $19(43 \%)$ & $(32 \%)$ & $(22 \%)$ & $2(11 \%)$ & $7(35 \%)$ \\
\hline$\# 10$ & $\begin{array}{l}\text { University of } \\
\text { Pittsburgh }\end{array}$ & $\begin{array}{l}\text { School of Information } \\
\text { Sciences }\end{array}$ & 88 & $17(20 \%)$ & $(18 \%)$ & $6(36 \%)$ & $1(6 \%)$ & $7(40 \%)$ \\
\hline$\# 13$ & $\begin{array}{l}\text { Florida State } \\
\text { University }\end{array}$ & $\begin{array}{l}\text { School of Library and } \\
\text { Information Studies }\end{array}$ & 52 & $17(35 \%)$ & $3(18 \%)$ & $3(18 \%)$ & $2(11 \%)$ & $9(52 \%)$ \\
\hline$\# 14$ & $\begin{array}{l}\text { University of } \\
\text { California--Los } \\
\text { Angeles } \\
\end{array}$ & $\begin{array}{l}\text { Department of } \\
\text { Information Studies }\end{array}$ & 198 & $38(20 \%)$ & $17(44 \%)$ & $8(22 \%)$ & 0 & $13(34 \%)$ \\
\hline & $\begin{array}{l}\text { *Average \% of IT } \\
\text { Courses in Top } 14 \text { LIS } \\
\text { Schools }\end{array}$ & & & $33 \%$ & $28 \%$ & $26 \%$ & $12 \%$ & $34 \%$ \\
\hline
\end{tabular}

NOTE: $\quad$ 1. Selected Graduate Schools of LIS (Rank score =>3.8) from US News \& World Report 2013 Best Schools Ranking List

2. Only GSLIS of Simmons College is not iSchool

Based on the data collected (see Table 1 and Table 2), the data analysis and comparative studies were conducted to investigate the conclusions. 


\section{Data Analysis and Comparative Studies}

From the information provided in Table 1, all selective LIS Schools (top 14 of best LIS Schools in the USA) have a long history of LIS education, and all are iSchools except for the Graduate School of Library and Information Science, Simmons College. Those LIS Schools were also as the top ranked Digital Librarianship programs and Information Systems programs by US News \& World Report 2013. From reviewing information on their websites, half of these LIS schools (7 of 14) offer IT related degrees from LIS school programs, or have merged together with Computer Science Programs or Information Technology Programs. Recently, the School of Library and Information Science, Indiana University has merged with their Computer Science and Informatics program The School of Information, University of Michigan at Ann Arbor has changed to offer Master of Science in Information instead of the traditional Master of Library and Information Science; the University of Illinois at Urbana-Champaign has offered multiple IT based degree programs such as Specialization in Data Curation, Socio-technical Data Analytics, Certificate of Advanced Study in Digital Libraries. The School of Information Studies at Syracuse University has offered "Master of Science in Telecommunications and Network Management", Certificates for Data Science, Digital Libraries, Information Systems and Telecommunication Management, and Global Enterprise Technology. The College of Information Science and Technology, Drexel University offered "Master of Science in Information Systems (MSIS)" and "Master of Science in Software Engineering (MSSE)".

Half of these top 14 LIS Schools are members of WISE and cooperate and collaborate in LIS education through distance learning. Many of the collaborated and shared online courses are information technology related courses (Courses collaborated and shared through WISE). The IT related courses through WISE could be shared and supplemented the faculty in different areas of skills and knowledge for IT and Information Science, in addition to meeting special needs from the LIS students. Successful collaborations in WISE are good examples to represent that IT courses enhance and implement the LIS Schools collaborations through online education.

In Table 2 Selective LIS Schools with Their IT Courses in Programs, various data about the IT related courses offered by those top 14 LIS Schools are listed.

The data explored in Table 2 demonstrate that IT has positively impacted on LIS educational programs. Along with IT rapidly changing and developing, new IT courses are also consistently created and updated by LIS faculty to meet the corresponding skills and knowledge needed by LIS professionals working in libraries and information agencies. The increasing numbers of new courses in those LIS schools indicate that IT related courses enhanced the quantities and qualities of curriculum of LIS education.

The IT related courses offered by LIS Schools were generally $20 \%-30 \%$ of the total number of courses provided in their programs. The higher ranked LIS Schools were with higher ranked positions in Information Systems and Digital Librarianship programs, such as School of Information, University of Michigan at Ann Arbor (62\% of courses are IT related), and School of Information Studies, Syracuse University (49\% of courses are IT related), of which both were ranked as number 1 on Information Systems programs (See in Table 1). College of Information Studies, University of Maryland at College Park (43\% of courses are IT related) and College of Information Science and Technology, 
Drexel University ( $42 \%$ of courses as IT related) were ranked as top 10 in information systems programs. The other LIS schools offered IT courses that were about $31 \%$ of the whole programs' courses, such as University of Illinois (28\% of courses as IT related), University of Washington (32\%), Indiana University (33\% of courses as IT related) and Florida State University (35\%) also were ranked highly in information systems or digital librarianship programs. On average, all of the top 14 best ranked LIS schools offered IT courses as over $33 \%$ of the total numbers of their courses. These data did significantly demonstrate the trend of LIS educational programs for their curriculum design, i.e., increasingly implement and add IT courses.

Actually, it was also found that many of the non-IT courses do have IT-related content. For instance, traditional librarianship courses such as library management, cataloging, or reference services, also have many content areas that are related to IT skills and knowledge. From this point of view, the percentages of IT-related courses are much higher than the data showed only from those courses with titles or descriptions of courses related to IT.

The categories of IT courses were presented in Table 2 into four categories: Web/Social Networks, Digital Resources/Metadata, Computers/Networks/Programming, Database Design and System Management. The data of the percentages (percentage of the total number of IT courses) in Table 2 show that courses of "Database Design and System Management" (34\% of IT courses offered) would be more often offered or needed for LIS students than the other categories of IT courses; the courses for Web related courses including managing electronic resources (28\% of IT courses offered) and Digital Resources and Metadata Processes (26\%) could be also considered as important content, or, more needed by LIS students for LIS curricula. The courses for computer equipment, programming and networking (12\%) were mostly seen as computer technicians' duties. Most professional librarians might not do such work so LIS students might not take as many of those courses as those on databases \& systems management, web interface design and metadata.

However, from this data analysis, we could see one important issue, that is, no matter how many IT courses are offered by LIS schools, LIS schools' curricula should still include processing/organizing information resources and providing information services, which are services that are different from those required by IT professionals whose focus is on creating/producing IT software and hardware programs. Therefore, one-third to one half of the IT courses provided in LIS curricula could be considered as a reasonable proportion. The other two-thirds or half of these courses should be about the organization of information, processing information, providing information services and managing information systems which would be the major duties of the profession, and should be considered as the majority of courses provided to LIS students. The skills and knowledge for library and information science (either two-thirds and/or half of the total) with IT skills and knowledge (as one-third and/or half of the amount) would equip the LIS professionals to meet the needs of libraries and information agencies.

\section{Summary}

From analyzing the IT courses offered from top 14 of the best LIS schools in the US, the ideal curriculum for LIS schools for IT related courses could be: 
- to arrange and design one third or half of the whole number of courses as IT focused courses in the curriculum (besides the IT related contents also being covered in other courses), depending on the different focus for each of the LIS schools programs;

- those IT related courses should focus on Database and Systems Management, Information Organization (such as metadata on digital resources) and Information Services (web interfaces design for information services ) as the "Core" courses;

- collaboration and sharing IT courses among LIS Schools through online education will be an efficient way to enhance and develop the LIS education for IT related contents, which is possible and should be extended. WISE is an efficient organization to implement and enhance this issue.

- Along with IT development in libraries and information agencies, the competencies of LIS professionals should be constantly updated and ensure updating IT skills and knowledge. LIS education and curriculum design would follow the practical needs of information services. The essential skills and knowledge for IT, such as organizing information resources, web interfaces for user services, databases and systems management for information services would be necessarily required as essential background and should be kept updated by all LIS professionals, LIS administrators, including faculty of LIS education.

\section{References}

2014 Best Library \& Information Studies Schools. US News and World Report, Retrieved from http://grad-schools.usnews.rankingsandreviews.com/best-graduate-schools/top-libraryinformation-science-programs

The College of Information Science and Technology, Drexel University. Retrieved from http://www.ischool.drexel.edu/PS/GraduatePrograms

Courses Collaborated and Shared through WISE. Retrieved from http://www.wiseeducation.org/media/documents/2009/1/wise.pdf

Graduate School of Library and Information Science, University of Illinois at UrbanaChampaign. Retrieved from http://www.lis.illinois.edu/academics/programs/specializations

iSchools Caucus (iSchools Organization). Retrieved from: http://ischools.org/about/charter/

iSchools Directory. Retrieved from http://ischools.org/directory/

Markey, K. (2004). Current Educational trends in Library and Information Science Curricula. Journal of Education for Library and Information Science, 45(4), 317-39.

Mathews, J. M. \& Pardue, H. (2009). The Presence of IT Skill Sets in Librarian Position Announcements. College and Research Libraries, 70(3), 250-57.

Membership of WISE (Web-Based Information Science Education). Retrieved from http://www.wiseeducation.org/ 
Michalko, J., Malpas, C, \& Arcolio, A. (2010, March). Research Libraries, Risk and Systematic Change, OCLC Research. Retrieved from http://www.oclc.org/research /publications/library/2010/2010-03.pdf .

Nonthacumjane, P. (2011). Key skills and competencies of a new generation of LIS professionals. IFLA Journal, 37(4), 280-288.

Rank position of Digital Librarianship. US News \& World Report. Retrieved from http://gradschools.usnews.rankingsandreviews.com/best-graduate-schools/top-library-information-scienceprograms/digital-librarianship-rankings

Rank positions of Information Systems. US News \& World Report. Retrieved from http://gradschools.usnews.rankingsandreviews.com/best-graduate-schools/top-library-information-scienceprograms/information-science-rankings? int $=\mathrm{d} 16 \mathrm{~d} 8 \mathrm{~d}$

Riley-Huff, D. A. \& Rholes, J. M. (2011). Librarians and Technology Skill Acquisition: Issues and Perspectives. Information Technology and Libraries, 30(3), 129-140.

School of Information, University of Michigan at Ann Arbor. Retrieved from https://www.si.umich.edu/academics/msi/msi-degree-components

School of Information Studies, Syracuse University. Retrieved from: http://coursecatalog.syr.edu/2012/schools/ischool/

School of Library and Information Science, Indiana University at Bloomington. Retrieved from http://ils.indiana.edu/news/merge.php

Zhou, Y. (1996). Analysis of Trends in Demand for Computer-Related Skills for Academic Librarians from 1974-1994. College \& Research Libraries, 57 (3), 259-72. 